\title{
An Investigation of Selected Socio-Demographic Factors with Aplastic Anemia in Pakistan: A Case-Control Study
}

\author{
Muhammad Asif Syed (D' \\ Aneela Atta Ur Rahman ${ }^{2}$ \\ Abdul Ghani ${ }^{3}$ \\ Muhammad Nadeem Shah Syed (iD) ${ }^{4}$ \\ Muhammad llyas Siddiqui (D) ${ }^{2}$ \\ Hina Riaz ${ }^{5}$ \\ Feriha Fatima Khidri (iD ${ }^{6}$ \\ Nayyar Nawaz Baloch'
}

'Field Epidemiology Laboratory Training Program (FELTP), Karachi, Pakistan;

${ }^{2}$ Department of Community Medicine \& Public Health Sciences, Liaquat University of Medical and Health Sciences, Jamshoro, Pakistan; ${ }^{3}$ Department of Health, Jam Ghulam Qadir Government Teaching Hospital, Hub, Pakistan;

${ }^{4}$ National Emergency Operation Center, National Stop Transmission of Polio (N-STOP), Islamabad, Pakistan; ${ }^{5}$ Department of Physiology/Medical Research Centre, Liaquat University of Medical and Health Sciences, Jamshoro, Pakistan; ${ }^{6}$ Medical Research Centre, Bilawal Medical College, Jamshoro, Pakistan
Correspondence: Muhammad Asif Syed Field Epidemiology Laboratory Training Program (FELTP), Karachi, Sindh, Pakistan Tel +0092-333-286-34-77

Email asif.mph@gmail.ccom
Introduction: In Pakistan, the incidence rate of aplastic anemia is 3.5 cases/million. The associated risk factors are exposure to pesticides, chemicals, and some drugs. The link between aplastic anemia and socio-demographic factors is debatable.

Purpose: We conducted this study to investigate the role of socio-economic and demographic factors with aplastic anemia.

Methodology: A total of 191 lab-confirmed incident cases of aplastic anemia were identified from the tertiary hospital of Karachi-Pakistan in between 2015 and 2018. Age and gendermatched 694 controls were randomly selected from the same institute admitted or visited for other non-neoplastic conditions. Socio-demographic and exposure information was gathered using a data collection form. Adjusted odds ratios (aORs) and 95\% confidence intervals (CIs) were computed for selected socio-demographic factors.

Results: Among socio-demographic factors, significant associations of aplastic anemia risk emerged for illiteracy (aOR: 2.3; 1.5; 3.5) occupation (any type) (aOR: $2.1 ; 1.7 ; 2.5$ ), living in rural environments (aOR: $2.9 ; 1.9 ; 4.2)$. The odds of aplastic anemia increased with the age group $31-50$ years (aOR: $1.8 ; 1.7 ; 3.5$ ) and $>50$ years (aOR: $2.5 ; 2.1 ; 4.2$ ). We observed no association of income with the risk of aplastic anemia.

Conclusion: This study highlights the importance of socio-demographic factors as a risk factor for the development of aplastic anemia in the population of Pakistan. In order to reduce disease incidence, health education program and use of personal protective equipment and organization of screening camps in high-risk population is warranted.

Keywords: aplastic anemia, Socio-demographic factors, case-control study, Pakistan

\section{Introduction}

Aplastic anemia is a rare hematological disorder with a case fatality rate of $34 \% .{ }^{1}$ It is defined as pancytopenia associated with hypocellular bone marrow. ${ }^{2}$ Aplastic anemia appears secondary to the immunological destruction of the hematopoietic stem cells caused by host and environmental factors. ${ }^{3}$ Established risk factors for aplastic anemia are exposure to medications, ${ }^{4}$ chemicals, ${ }^{5}$ and environmental factors. ${ }^{6}$

The socio-demographic factors such as living in rural settings, low socioeconomic status, illiteracy, and age $>15$ years are recognized as a risk factor of aplastic anemia. $^{7,8}$ The Western residents showed peaks of aplastic anemia cases at 15-29 years and $>60$ years $^{1}$ while in the Asian population highest number was observed in the age group 15-24 years. $^{3}$ The difference may be attributed to change in 
environmental factors and life circumstances. ${ }^{9}$ The incidence of the disease is high in males as they are exposed to potentially toxic agents in occupational settings. ${ }^{4,10}$ Low socioeconomic status and rural population have a significant association with increased risk of aplastic anemia as reported from low middle income countries. $^{3,7,8}$ Both variables (low socio-economic status and living in the rural areas) may be proxy indicators for exposure to environmental factors that could cause aplastic anemia. Illiteracy was also significantly associated with the risk of aplastic anemia, and the chance of aplastic anemia increased with no levels of education. In other words, illiterate individuals remained at higher risk of

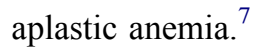

In Pakistan, there was no published study on sociodemographic variables as a risk factor of aplastic anemia. Therefore, a large case-control study was done to explore the association between selected socio-demographic factors with aplastic anemia in Pakistan's population.

\section{Methods}

We have done a hospital-based case-control study with 191 cases 696 controls. All participants were residents of Pakistan. New cases, diagnosed between January 2015 and December 2018 were selected from the National Institute of Blood Borne Diseases and Bone Marrow Transplantation Center, Karachi, Sindh. All cases were patients of aplastic anemia confirmed through bone marrow examination.

Controls were matched by age group and gender. All were randomly selected from the same hospital among individuals who visited or were admitted for road-trafficaccident trauma, acute abdominal emergencies, acute infections and other conditions (conjunctivitis, cellulitis, abscess and dengue). Controls did not have aplastic anemia or other blood disorder.

Cases and controls with a history of neutropenia or pancytopenia (lupus, HIV infection, hypersplenism) and severe hematologic diseases (neoplasia, neural tube defects, megaloblastic anemia) were excluded. The inherited bone marrow failure syndromes, paroxysmal nocturnal hemoglobinuria, history of organ transplantation, chemo, immunosuppressive, or radiotherapy were also conditions for exclusion.

A data collection form was used to gather information regarding age, sex, place of residence, education level, employment status, and monthly income. In addition, a family history of aplastic anemia (grandparents, parents, siblings, or cousins) was ascertained among study participants. The interview entailed questions about the history of exposure to medicine, radiation, and chemicals.

SPSS, version 22.0 was used for data analysis. We calculated the frequency and proportion for each categorical variable. A Chi-square test was run to identify the significance of the difference. The binary logistic regression model was applied to calculate the unadjusted associations of socio-demographic risk factors with aplastic anemia. The significant risk factor was further examined in multiple logistic regression models to estimate the adjusted association with a 95\% confidence interval. $P$-value $<0.05$ was considered statistically significant. Potential confounders (age, gender, place of residence, exposure to chemicals, radiations, drugs, and family history of aplastic anemia) were adjusted in a multiple logistic regression model.

The research was conducted after approval of the ethics review committee of Liaquat University of Medical and Health Sciences (NO. LUMHS/REC/-122 dated 02-012014). All participants (cases and controls) age $>18$ years gave informed consent before interviews while for participants $<18$ years consent was obtained from parents or guardian. This study complies with the Declaration of Helsinki.

\section{Results}

The median age of cases was 27 years (ranged 04-69 years). Eighty-four (44\%) belonged from the age group 16-30 years. On age stratification, significant difference $(P<0.05)$ was observed. Gender distribution did not vary significantly $(P=0.59)$. Place of residence had significance with regard to aplastic anemia $(P<0.05)$. The majority of participants (cases 115 (60\%), controls 284 $(41 \%))$ were living in rural areas. Education-wise difference was found to be significant $(P<0.05)$, while monthly income was not significantly different $(P=0.588)$. Aplastic anemia in family members was higher in 30 $(15.7 \%)$ cases as compared to control $24(3.4 \%)$. There was a difference between the two groups $(P<0.001)$. On the basis ethnic five groups were formulated, there was a significant difference observed between the ethnic groups $(\mathrm{P}<0.02)$ Table 1.

Among 191 aplastic anemia cases, 99 (52\%) had moderate, $60(31 \%)$ severe, and 32 (17\%) were with very severe aplastic anemia. Table 2 shows the distribution of selected socio-demographical factors with types of aplastic anemia. 
Table I Selected Socio-Demographic Factors of 191 Cases of Aplastic Anemia and 694 Controls

\begin{tabular}{|c|c|c|c|}
\hline & $\begin{array}{c}\text { Cases } \\
\mathrm{N}=191 \text { (\%) }\end{array}$ & $\begin{array}{l}\text { Controls } \\
\mathrm{N}=696(\%)\end{array}$ & $P$ value \\
\hline \multicolumn{4}{|l|}{ Age Categories } \\
\hline $1-15$ years & 40 (20.9\%) & 98 (I4.1\%) & \multirow[t]{4}{*}{0.025} \\
\hline $16-30$ years & 84 (44.0\%) & 308 (44.3\%) & \\
\hline $3 \mathrm{I}-50$ years & 48 (25.1\%) & 196 (28.2\%) & \\
\hline$>50$ years & 19 (9.9\%) & 94 (I3.5\%) & \\
\hline \multicolumn{4}{|l|}{ Gender } \\
\hline Male & $129(68 \%)$ & $484(70 \%)$ & \multirow[t]{2}{*}{0.59} \\
\hline Female & $62(32 \%)$ & $212(30 \%)$ & \\
\hline \multicolumn{4}{|l|}{ Residence } \\
\hline Rural & 115 (60\%) & 284 (4I\%) & \\
\hline Urban & 76 (40\%) & $4 \mid 2$ (59\%) & \\
\hline \multicolumn{4}{|l|}{ Social Classes } \\
\hline$<10,000$ rupees & 34 (38.2\%) & I 44 (40.7\%) & 0.588 \\
\hline 10,000 to 20,000 & $29(32.6 \%)$ & II 6 (32.8\%) & 0.739 \\
\hline rupees & & & \\
\hline$>20,000$ rupees & $26(29.2 \%)$ & 94 (26.6\%) & \\
\hline \multicolumn{4}{|l|}{ Education level } \\
\hline No education & $80(42 \%)$ & 190 (27\%) & 0.01 \\
\hline Yes education & III (58\%) & 506 (73\%) & \\
\hline \multicolumn{4}{|l|}{ Occupation } \\
\hline Yes & 87 (46\%) & $258(37 \%)$ & \multirow[t]{2}{*}{0.42} \\
\hline No & 104 (54\%) & $438(63 \%)$ & \\
\hline \multicolumn{4}{|l|}{ Family History } \\
\hline No & 161 (84.3\%) & 672 (96.5\%) & \multirow[t]{2}{*}{$<0.001$} \\
\hline Yes & 30 (15.7\%) & 24 (3.4\%) & \\
\hline \multicolumn{4}{|l|}{ Ethnic group } \\
\hline Sindhi & 66 (34.6\%) & 222 (31.9\%) & \multirow[t]{7}{*}{0.02} \\
\hline Seraiki/Gujrati/ & 39 (20.4\%) & 88 (12.6\%) & \\
\hline Hindko & & & \\
\hline Urdu & $30(15.7 \%)$ & 132 (19.0\%) & \\
\hline Punjabi & 22 (11.5\%) & 136 (19.5\%) & \\
\hline Balochi & 22 (1 I.5\%) & 64 (9.2\%) & \\
\hline Pashtu & 12 (6.3\%) & 54 (7.8\%) & \\
\hline
\end{tabular}

Table 3 is showing that among socio-demographic factors, illiteracy (OR: 1.9; 1.3; 2.6), occupation (OR: $1.4 ; 1.0 ; 1.9)$, age group $31-50$ years (OR: $1.6 ; 1.0 ; 2.7$ ) and $>50$ years age (OR: $2.0 ; 1.0 ; 3.7)$ rural environments (OR: $2.1 ; 1.5 ; 3.0$ ) and family history of aplastic anemia (OR: 5.2, 95\% C.I.: 2.96-9.16) were significantly associated with aplastic anemia. This association remain significant $(\mathrm{aOR}=13.3,95 \%$ C.I.: 3.66-48.50) after adjustment of socio-demographic variables (age, gender, occupation employment, ethnicity and monthly income).

\section{Discussion}

In this case-control study, the odds of aplastic anemia increased with the age group 31-50 years (OR: 1.6) and $>50$ years (OR: 2.0). Similar odds of disease (4.36) in the age group $>50$ years were also reported in a study conducted in Sweden. ${ }^{11}$ The accumulation of exposures (radiation, harmful chemicals, medicine, and viruses) and age-associated changes in a biochemical process add the risk of cancer.

In Pakistan, about $63 \%$ population resides in rural areas. They have increased chances of exposure to several toxic substances, medicine or pathogenic agents that may contribute to the development of aplastic anemia. In addition, the residents of rural areas are facing more difficulty accessing health-care services, which may limit the early detection and treatment of disease. We observed rural residence is a significant risk factor of aplastic anemia with an odds ratio of 2.9. Our results were consistent with Taj et $\mathrm{al}^{7}$ who reported that rural residents had 2.6 odd of acquiring aplastic anemia compared to urban residents.

In our study, the risk of aplastic anemia increases with no education (OR: 2.3). However, Taj et al reported an increased year of education as a protective effect against aplastic anemia. ${ }^{7}$ Education plays an important role in the selection of occupation, access to and use of health-care services, and participation in health promotion and screening programs. On the other hand, the association of aplastic anemia with educational status was not found to be significant in a study conducted in India. ${ }^{8}$

In our study, low socioeconomic status did not show any association $(\mathrm{OR}=0.9)$ with aplastic anemia. On the other hand, studies conducted in India and Thailand have shown that aplastic anemia is more common in low socioeconomic class as compared to high socioeconomic. ${ }^{8,12}$ Our finding may be attributed to the low response rate against this variable as only $63 \%$ population gave information regarding their socioeconomic status. Lower socioeconomic status is an indirect indicator of increased exposure to environmental risk factors that have been connected to the pathogenesis of aplastic anemia. ${ }^{12}$

Moreover, our research noticed positive aplastic anemia family history is a risk factor with an odds ratio of 5.2. 
Table 2 Selected Socio-Demographic Factors of 191 Cases with Types of Aplastic Anemia

\begin{tabular}{|c|c|c|c|c|c|c|}
\hline Age Group & $\begin{array}{l}\text { Total } N=|9| \\
(\%)\end{array}$ & $\begin{array}{l}\text { Moderate AA n=99 } \\
\text { (\%) }\end{array}$ & $\begin{array}{l}\text { Severe AA } n=60 \\
(\%)\end{array}$ & $\begin{array}{l}\text { Very Severe AA } n=32 \\
\text { (\%) }\end{array}$ & $\mathbf{x}^{2}$ & $P$ value \\
\hline $\begin{array}{l}1-15 \text { Year } \\
16-30 \text { Year } \\
31-50 \text { Year } \\
>50 \text { Year }\end{array}$ & $\begin{array}{l}40(21 \%) \\
84(44 \%) \\
48(25 \%) \\
19(10 \%)\end{array}$ & $\begin{array}{l}22(22 \%) \\
36(36 \%) \\
24(24 \%) \\
17(17 \%)\end{array}$ & $\begin{array}{l}12(20 \%) \\
30(50 \%) \\
16(27 \%) \\
2(3 \%)\end{array}$ & $\begin{array}{l}6(19 \%) \\
18(56 \%) \\
8(25 \%) \\
0(0 \%)\end{array}$ & 14.1 & 0.02 \\
\hline \multicolumn{7}{|l|}{ Gender } \\
\hline $\begin{array}{l}\text { Male } \\
\text { Female }\end{array}$ & $\begin{array}{l}129(68 \%) \\
62(32 \%)\end{array}$ & $\begin{array}{l}68(69 \%) \\
31(31 \%)\end{array}$ & $\begin{array}{l}41(68 \%) \\
19(32 \%)\end{array}$ & $\begin{array}{l}20(63 \%) \\
12(38 \%)\end{array}$ & 0.06 & 0.7 \\
\hline \multicolumn{7}{|l|}{ Residence } \\
\hline $\begin{array}{l}\text { Urban } \\
\text { Rural }\end{array}$ & $\begin{array}{l}76(40 \%) \\
I I 5(60 \%)\end{array}$ & $\begin{array}{l}46(46 \%) \\
53(54 \%)\end{array}$ & $\begin{array}{l}16(27 \%) \\
44(73 \%)\end{array}$ & $\begin{array}{l}14(44 \%) \\
18(56 \%)\end{array}$ & 6.3 & 0.04 \\
\hline \multicolumn{7}{|l|}{ Income category } \\
\hline $\begin{array}{l}<10,000 \text { Pak rupees } \\
10,000 \text { to } 20,000 \text { Pak } \\
\text { rupees } \\
>20,000 \text { Pak rupees }\end{array}$ & $\begin{array}{l}34(18 \%) \\
29(15 \%) \\
26(14 \%)\end{array}$ & $\begin{array}{l}20(20 \%) \\
15(15 \%) \\
8(8 \%)\end{array}$ & $\begin{array}{l}12(20 \%) \\
10(17 \%) \\
10(17 \%)\end{array}$ & $\begin{array}{l}2(6 \%) \\
4(13 \%) \\
8(25 \%)\end{array}$ & 8.4 & 0.07 \\
\hline \multicolumn{7}{|l|}{ Education } \\
\hline $\begin{array}{l}\text { No } \\
\text { Yes }\end{array}$ & $\begin{array}{l}80(42 \%) \\
\mathrm{III}(58 \%)\end{array}$ & $\begin{array}{l}44(44 \%) \\
55(56 \%)\end{array}$ & $\begin{array}{l}24(40 \%) \\
36(60 \%)\end{array}$ & $\begin{array}{l}12(38 \%) \\
20(63 \%)\end{array}$ & 30 & $<0.00$ \\
\hline \multicolumn{7}{|l|}{ Occupation } \\
\hline $\begin{array}{l}\text { Yes } \\
\text { No }\end{array}$ & $\begin{array}{l}87(46 \%) \\
104(54 \%)\end{array}$ & $\begin{array}{l}49(49 \%) \\
50(51 \%)\end{array}$ & $\begin{array}{l}19(32 \%) \\
41(68 \%)\end{array}$ & $\begin{array}{l}19(59 \%) \\
13(41 \%)\end{array}$ & 7.7 & 0.02 \\
\hline \multicolumn{7}{|l|}{ Family history } \\
\hline $\begin{array}{l}\text { No } \\
\text { Yes }\end{array}$ & $\begin{array}{l}161(84 \%) \\
30(16 \%)\end{array}$ & $\begin{array}{l}80(81 \%) \\
19(19 \%)\end{array}$ & $\begin{array}{l}55(92 \%) \\
5(8 \%)\end{array}$ & $\begin{array}{l}26(81 \%) \\
6(19 \%)\end{array}$ & 3.5 & 0.16 \\
\hline \multicolumn{7}{|l|}{ Ethnicity } \\
\hline $\begin{array}{l}\text { Sindhi } \\
\text { Seraiki/Gujrati/ Hindko } \\
\text { Urdu } \\
\text { Punjabi } \\
\text { Balochi } \\
\text { Pashtu }\end{array}$ & $\begin{array}{l}66(35 \%) \\
39(20 \%) \\
30(16 \%) \\
22(12 \%) \\
22(12 \%) \\
12(6 \%)\end{array}$ & $\begin{array}{l}36(36 \%) \\
21(21 \%) \\
14(14 \%) \\
10(10 \%) \\
10(10 \%) \\
8(8 \%)\end{array}$ & $\begin{array}{l}20(33 \%) \\
12(20 \%) \\
8(13 \%) \\
6(10 \%) \\
10(17 \%) \\
4(7 \%)\end{array}$ & $\begin{array}{l}10(31 \%) \\
6(19 \%) \\
8(25 \%) \\
6(19 \%) \\
2(6 \%) \\
0(0 \%)\end{array}$ & 34 & $<0.00$ \\
\hline
\end{tabular}

Similarly, an excess of family consanguinity was reported among cases of aplastic anemia in Japan. ${ }^{14} \mathrm{~A}$ nonsignificant association (OR: $1.3 ; 0.6: 3.3$ ) of genetic and hematologic familial disease or parental consanguinity with aplastic anemia was reported from France. ${ }^{15}$ The risk associated with a family history of cancer may be attributed to genetic susceptibility, or shared environmental and lifestyle influences. ${ }^{13}$ The risk increased 2-3 fold (for few cancers) among those with a positive family history as compared to the general population. ${ }^{13}$

\section{Conclusion and Recommendations}

Age group ( $>30$ years), illiteracy, occupation, rural residence, and family history of aplastic anemia were identified as significant risk factors for aplastic anemia. Screening of individuals $>30$ years (with the presence 
Table 3 Binary Logistic Regression for Association Between Selected Socio-Demographic Factors and Aplastic Anemia (I9I Cases of Aplastic Anemia and 696 Control)

\begin{tabular}{|c|c|c|c|c|}
\hline Variables & Cases, $\mathbf{N}=|9|(\%)$ & Controls, N=696 (\%) & OR & 95\% C.I Lower Upper \\
\hline \multicolumn{5}{|l|}{ Age Categories } \\
\hline $1-15$ years & 40 (2।\%) & $98(14 \%)$ & Ref & \\
\hline $16-30$ years & 84 (44\%) & $308(44 \%)$ & 1.4 & $0.9-2.3$ \\
\hline $3 \mathrm{I}-50$ years & $48(25 \%)$ & $196(28 \%)$ & 1.6 & $1.0-2.7$ \\
\hline$>50$ years & $19(10 \%)$ & $94(14 \%)$ & 2.0 & I.0-3.7 \\
\hline \multicolumn{5}{|l|}{ Gender } \\
\hline Male & $129(68 \%)$ & 484 (70\%) & 0.9 & $0.6-1.2$ \\
\hline Female & $62(32 \%)$ & $212(30 \%)$ & & \\
\hline \multicolumn{5}{|l|}{ Residence } \\
\hline Rural & $115(60 \%)$ & $284(41 \%)$ & 2.1 & $1.5-3.0$ \\
\hline Urban & $76(40 \%)$ & $4 \mid 2(59 \%)$ & & \\
\hline \multicolumn{5}{|l|}{ Social Classes } \\
\hline$<10,000$ PKR & 34 (18\%) & 144 (2।\%) & Ref & \\
\hline $10,000-20,000$ PKR & 29 (15\%) & $116(17 \%)$ & 0.9 & $0.5-1.6$ \\
\hline$>20,000$ PKR & $26(14 \%)$ & $94(14 \%)$ & 0.8 & $0.4-1.5$ \\
\hline \multicolumn{5}{|l|}{ Education } \\
\hline No education & $80(42 \%)$ & $190(27 \%)$ & 1.9 & $1.3-2.6$ \\
\hline Yes Education & III (58\%) & 506 (73\%) & & \\
\hline \multicolumn{5}{|l|}{ Occupation } \\
\hline Yes & 87 (46\%) & $258(37 \%)$ & 1.4 & $1.0-1.9$ \\
\hline No & $104(54 \%)$ & $438(63 \%)$ & Ref & \\
\hline \multicolumn{5}{|c|}{ Positive family $\mathrm{H} /$ of aplastic anemia } \\
\hline Yes & $30(15.7 \%)$ & $24(3.4 \%)$ & 5.2 & $2.96-9.16$ \\
\hline No & $16 \mid(84.3 \%)$ & $672(96.5 \%)$ & Ref & \\
\hline
\end{tabular}

of risk factors for aplastic anemia) is encouraged. Initiation of the disease-specific awareness campaigns especially in rural areas and promotion of personal protective equipment use among people involved in high-risk occupations is highly recommended. Government develops a strategy to fight against illiteracy and poverty. Our results deserve to be confirmed by additional studies with larger samples in different regions of Pakistan.

\section{Strengths and Limitation}

We selected control from the hospital as they are easier to identify and more likely to participate as compared to general population controls. They have a decrease chance of selection and recall bias as they generally come from the same source population and they are sick with a different diagnosis respectively.

The current study has some limitations. First, this is a hospital-based study and it is very difficult to represent the entire population. Case-control study design renders some findings difficult to interpret due to a possibility of recall bias. Another limitation may be that some suspected risk factors for aplastic anemia were not included in our analysis, such as exposure to chemicals, pesticides, medication, and radiation.

\section{Acknowledgments}

We acknowledge the help extended in compiling the patient demographic data by the Dr Aamir Hussain fellow of FELTP-Pakistan. 


\section{Disclosure}

The authors report no conflicts of interest in this study.

\section{References}

1. Mary J, Baumelou E, Guiguet M. Epidemiology of aplastic anemia in France: a prospective multicentric study. The French cooperative group for epidemiological study of aplastic anemia; 1990.

2. Young NS. Acquired aplastic anemia. Ann Intern Med. 2002;136 (7):534-546. doi:10.7326/0003-4819-136-7-200204020-00011

3. Issaragrisil S, Kaufman DW, Anderson T, et al. The epidemiology of aplastic anemia in Thailand. Blood. 2006;107(4):1299-1307. doi:10.1182/blood-2005-01-0161

4. Maluf EM, Pasquini R, Eluf JN, Kelly J, Kaufman DW. Aplastic anemia in Brazil: incidence and risk factors. Am J Hematol. 2002;71 (4):268-274. doi:10.1002/ajh.10232

5. Kaufman DW, Issaragrisil S, Anderson T, et al. Use of household pesticides and the risk of aplastic anaemia in Thailand. The Aplastic anemia study group. Int $J$ Epidemiol. 1997;26(3):643-650. doi:10.1093/ije/26.3.643

6. Shadduck R, Beutler E, Lichtman M, Coller B, Kipps T. Williams' Hematology. 1995.

7. Taj M, Shah T, Aslam SK, et al. Environmental determinants of aplastic anemia in Pakistan: a case-control study. J Public Health. 2016;24(5):453-460. doi:10.1007/s10389-016-0743-6

8. Malhotra P, Gella V, Guru Murthy GS, Varma N, Varma S. High incidence of aplastic anemia is linked with lower socioeconomic status of Indian population. $J$ Public Health. 2016;38(2):223-228. doi:10.1093/pubmed/fdv027
9. Kojima S. Aplastic anemia in the Orient. Int J Hematol. 2002;76 (2):173-174. doi:10.1007/BF03165112

10. Issaragrisil S, Leaverton $\mathrm{PE}$, Chansung $\mathrm{K}$, et al. Regional patterns in the incidence of aplastic anemia in Thailand. Am J Hematol. 1999;61 (3):164-168. doi:10.1002/(SICI)1096-8652(199907)61:3<164::AID$\mathrm{AJH} 2>3.0 . \mathrm{CO} ; 2-\mathrm{R}$

11. Vaht K, Göransson M, Carlson K, et al. Incidence and outcome of acquired aplastic anemia: real-world data from patients diagnosed in Sweden from 2000-2011. Haematologica. 2017;102(10):1683. doi:10.3324/haematol.2017.169862

12. Issaragrisil S, Kaufman DW, Anderson TE, et al. An association of aplastic anaemia in Thailand with low socioeconomic status. $\mathrm{Br}$ $J$ Haematol. 1995;91(1):80-84. doi:10.1111/j.1365-2141.1995. tb05248.x

13. Hemminki K, Risch N. Genetic epidemiology of cancer: interpreting family and twin studies and their implications for molecular genetic approaches Cancer Epidemiol. Biomark Cancer Epidemiol Biomark Prev. 2002;11(4):423-426.

14. Nagai M, Ohta A, Nishina M, Shimada N, Nakao S, Kurokawa M. Sex, age and other epidemiological characteristics of Aplastic anemia patients in Japan. Int $J$ Epidemiol. 2015;44(suppl_1):i170. doi:10.1093/ije/dyv096.236

15. Baumelou E, Guiguet M, Mary J. Epidemiology of aplastic anemia in France: a case-control study. I. Medical history and medication use. The French cooperative group for epidemiological study of aplastic anemia. Blood. 1993;81(6):1471-1478. doi:10.1182/blood. V81.6.1471.1471
International Journal of General Medicine

\section{Publish your work in this journal}

The International Journal of General Medicine is an international, peer-reviewed open-access journal that focuses on general and internal medicine, pathogenesis, epidemiology, diagnosis, monitoring and treatment protocols. The journal is characterized by the rapid reporting of reviews, original research and clinical studies

\section{Dovepress}

across all disease areas. The manuscript management system is completely online and includes a very quick and fair peer-review system, which is all easy to use. Visit http://www.dovepress.com/ testimonials.php to read real quotes from published authors. 